\author{
Iwona Maciejewska ${ }^{1}$
}

\title{
ZA CÓŻ CHWALIĆ NIEWIASTĘ? EWOLUCJA KONWENCJI PANEGIRYCZNEJ W RAMIE WYDAWNICZEJ EDYCJI CZASÓW SASKICH
}

Tadeusz Bieńkowski w artykule opublikowanym przed ponad trzydziestu laty stwierdził, iż w wieku XVII ,trudno wyobrazić sobie utwór ogłoszony drukiem pozbawiony wszelkich akcentów panegirycznych. Jeśli nawet treść nie miała takich akcentów, to panegiryczna z reguły była dedykacja utworu"². Podobną tezę, nawet jeśli wydaje się ona nieco przesadzona, można z pewnością odnieść również do praktyki edytorskiej doby saskiej. W przywołanej opinii wskazującej na powszechność panegiryzmu w dawnym piśmiennictwie zawiera się również istotne dla podjętych tu rozważań wskazanie - gdzie najlepiej i najpewniej tego typu treści szukać. Dedykacja, zwana także przypisaniem, która przybierać mogła zarówno formę wierszowaną, jak i prozaiczną, stanowiła w staropolszczyźnie istotny i częsty element ramy wydawniczej3. Tu miejsce znajdowały rozbudowane pochwały i hołdy kierowane pod adresem ważnych i mniej ważnych osobistości, wśród których częstokroć szukano hojnego mecenasa i wpływowego opiekuna. Jak pokazały dotychczasowe badania, stopień nasycenia dedykacji panegiryzmem bywał zróżnicowany. Nie zawsze amplifikowana laudacja była w nich elementem pierwszoplanowym, czasem mogła być przytłumiona innymi istotnymi dla autora treściami, a jej natężenie zależało od relacji łączących twórcę $\mathrm{z}$ adresatem przypisania ${ }^{4}$. Jednak, jak zauważa Bieńkowski, od połowy XVI wieku styl panegiryczny wyraziście określił charakter większości dedykacji ${ }^{5}$, co uznawano wówczas za ogólnie akceptowaną normę.

Wskazano już wielokrotnie na uwarunkowania sprzyjające rozwojowi owych tendencji, w tym oczywisty wpływ systemu edukacji - „,szkoła dawała nawyk panegiryzowania i nawyk myślenia w trybie panegiryku, i to zarówno ze

1 Uniwersytet Warmińsko-Mazurski w Olsztynie.

2 T. Bieńkowski, Panegiryk a życie literackie w Polsce XVI i XVII w., [w:] Z dziejów życia literackiego $w$ Polsce XVI $i$ XVII wieku, red. H. Dziechcińska, Studia Staropolskie, t. 48, Wrocław 1980, s. 185.

3 R. Ocieczek, O różnych aspektach badań literackiej ramy wydawniczej, [w:] O literackiej ramie wydawniczej w ksiażkach dawnych, red. eadem, Prace Naukowe Uniwersytetu Śląskiego, nr 1099, Katowice 1990, s. 7-10.

4 Eadem, ,Staworodne wizerunki”. O wierszowanych listach dedykacyjnych z XVII wieku, Prace Naukowe Uniwersytetu Śląskiego, nr 477, Katowice 1982.

5 T. Bieńkowski, op. cit., s. 189. 
strony klienta, jak i mecenasa" ${ }^{9}$. Treści o takim charakterze znajdowały ujście w przeróżnych formach gatunkowych powstających przy niezliczonych uroczystych okazjach, których w dawnej Polsce nie brakowało. Trudno się zatem dziwić, iż zadomowiły się na dobre w ramie wydawniczej dzieł oddawanych do druku, których autor lub też wydawca liczył na wsparcie unieśmiertelnionego „Sławorodnym wizerunkiem” potencjalnego lub rzeczywistego protektora. Choć autorzy oświecenia dobitnie krytykowali tradycyjny, silnie skonwencjonalizowany wzorzec panegirycznych dedykacji ${ }^{7}$, to jednak zmiana powszechnych przyzwyczajeń nie była sprawą łatwą. Interesujące nas tu czasy saskie utrwaliły bowiem funkcjonujące rozwiązania, co potwierdza przeprowadzona przez Bożenę Mazurkową analiza przypisań zamieszczanych w edycjach z lat czterdziestych i pięćdziesiątych XVIII wieku, w których wyraźnie zaznacza się obecność wzorca panegiryczno-genealogicznego ${ }^{8}$. Skoro zatem pierwsza połowa tegoż stulecia to kontynuacja wcześniej obowiązujących praktyk, gdzie należy poszukiwać zasugerowanej w temacie ewolucji? Na jakim polu dostrzec można zmiany i co je warunkuje? Nie dotyczą one bynajmniej zasadniczych reguł czy chwytów rządzących wypowiedzią o charakterze panegirycznym. Innowacja tkwi bowiem gdzie indziej i wiąże się z odpowiedzią na pytanie: kto kogo i za co chwali?

Otóż czasy saskie, jak zauważyła Paulina Buchwald-Pelcowa, to swoisty konglomerat „starego" i ,nowego". Novum będzie z pewnością wyraziste uaktywnienie się $\mathrm{w}$ życiu literackim tego okresu kobiet, mniej lub bardziej wykształconych, oczytanych, piszących i inspirujących zjawiska kulturalne ${ }^{10}$. Jak ten fakt przekłada się na zajmujące nas tu zjawisko panegiryzmu? Konsekwencje owych zmian dostrzec można, $m$. in. w ramie wydawniczej opublikowanych bądź przeznaczonych do druku tekstów. Kobieta pojawia się tam w różnych rolach. Po pierwsze, staje się autorką, która, przestrzegając utrwalonych reguł, konstruuje panegiryczną dedykację, skierowaną bądź do mężczyzny, bądź do przedstawicielki swojej płci. Po drugie, również jako autorka, bywa adresatką przypisania, do której wydawca czy inna osoba zwraca

6 Ibidem, s. 188.

7 B. Mazurkowa, Literacka rama wydawnicza dziet Franciszka Dionizego Kniaźnina (na tle porównawczym), Prace Naukowe Uniwersytetu Śląskiego, nr 1397, Katowice 1993, s. 20-24.

8 Ibidem, s. 25.

9 P. Buchwald-Pelcowa, „Stare” $i$ „nowe” $w$ czasach saskich, [w:] eadem, Historia literatury i historia ksiqżki. Studia nad ksiqżkq i literaturq od średniowiecza po wiek XVIII, Kraków 2005, s. 523-573.

10 H. Dziechcińska, Maria Beata Zawiszanka - ttumaczka francuskiego romansu, [w:] Barok polski wobec Europy. Sztuka przekładu, red. A. Nowicka-Jeżowa, M. Prejs, Warszawa 2005, s. 277-278. 
się $\mathrm{z}$ określonymi treściami, najczęściej związanymi z jej artystycznymi dokonaniami. Wreszcie po trzecie, pozostaje w roli wcześniej nam znanej, jest odbiorczynią pochwalnych wynurzeń, postrzeganą jako potencjalna mecenaska czy opiekunka ofiarowanego jej dzieła. Z tych najważniejszych wskazanych wariantów wynika, że kobieta może być zarówno twórczynią panegirycznego wizerunku, jak i jego bohaterką.

$\mathrm{Z}$ tym drugim przypadkiem w staropolszczyźnie mamy do czynienia wielokrotnie, oczywiście najczęściej w gatunkach okolicznościowych, ale pochwała niewiast pojawiała się we wcześniejszych stuleciach także w kierowanych doń dedykacjach. Paniom i pannom przypisywano zazwyczaj utwory o treści religijnej bądź romansowej, ale także takie, które propagowały określone wzorce osobowe, stanowiły swoiste zwierciadła cnót. Wówczas tendencja panegiryczna, wyrażająca się w nagromadzeniu i wyolbrzymieniu zalet adresatki, wyraziście wspierała tendencje parenetyczne ${ }^{11}$. A za cóż można było sławić kobiety, skoro nie sprawowały eksponowanych funkcji publicznych, nie toczyły wojen, nie brylowały w świecie polityki? Renarda Ocieczek przywołuje poglądy Jana Ursinusa, który wśród elementów godnych wywyższenia wskazuje pochodzenie, urodę, wstydliwość, płodność, dzieci, majątek, a przede wszystkim: cnotę i uczciwość ${ }^{12}$. Ta lista ma uzasadnienie w rolach, poprzez które tradycyjnie postrzegano kobietę. Miała być ona przede wszystkim dobrą, poczciwą żoną i matką troskliwie strzegącą domowego ogniska, wspierającą swoje alter ego, czyli ukochanego małżonka. Jeśli utwór był przypisany pannie, lista zalet była z konieczności nieco okrojona, ale wtedy amplifikowanej laudacji podlegały, np. uroda, skromność, wstydliwość, pobożność. Doskonałym przykładem może służyć pośmiertne wydanie dramatów Franciszki Urszuli Radziwiłłowej, które Jakub Pobóg Fryczyński zadedykował córkom księżnej - Teofili Konstancji i Karolinie Katarzynie. Obie kreuje na chodzące doskonałości, a ich zalety wywyższa poprzez zastosowanie kontrastu:

Śliczność albowiem urody innym źrzódłem swawoli, Wam statku wytwornego podnietą i przedziwną okrasą cnoty; zacność urodzenia innych w niepomiarkowane wynosi o sobie rozumienie, Was do najwyższej pobudza pokory $[\ldots]^{13}$.

11 A. Pizun-Maszczykowa, O staropolskich dedykacjach dla kobiet, [w:] Dzieto literackie i ksiqżka w kulturze. Studia i szkice ofiarowane Profesor Renardzie Ocieczek $w$ czterdziestolecie pracy naukowej i dydaktycznej, red. I. Opacki, przy współudz. B. Mazurkowej, Prace Naukowe Uniwersytetu Śląskiego, nr 2050, Katowice 2002, s. 418-421.

12 R. Ocieczek, „Staworodne wizerunki”..., s. 88.

13 J. P. Fryczyński, Dedykacyja..., [w:] F. U. Radziwiłłowa, Komedyje i tragedyje..., [Żółkiew] 1754, strony dedykacji bez paginacji. $Z$ tego wydania pochodzą wszystkie cytaty. 
Nota bene wysławiana ,najwyższa pokora” i „wytworny statek”, zwłaszcza w przypadku starszej księżniczki, budzić musi poważne zastrzeżenia w świetle relacji o jej postępkach przekazanej nam przez Marcina Matuszewicza ${ }^{14}$.

W dedykacjach skierowanych do kobiet zamężnych ich adresatki pojawiają się często w charakterze pośredniczek do łask małżonków i niejednokrotnie są wychwalane na tle swych partnerów ${ }^{15}$. Dodajmy, że owo tło często mocno się rozrasta i to właśnie mąż zostaje wykreowany na głównego bohatera przypisania. Uzupełniać pochwałę może również obszerna laudacja innych mężczyzn członków rodu, z którego dana niewiasta się wywodziła - ojców, braci, stryjów, kuzynów. Przykładem służy dedykacja skierowana do Barbary z Duninów Sanguszkowej, której Jakub Kazimierz Rubinkowski ofiarowuje opublikowany w 1741 roku romans Historyja o Chryzeidzie i Arymancie autorstwa swego syna Jana Karola $^{16}$. Torunianin, biegły w sztuce panegirycznych konceptów ${ }^{17}$, z dużym zaangażowaniem poszukuje pomysłów, aby wyrazić wszystkie przymioty, które dom Duninów „w bazylikę honorów przemieniły”, ale zgodnie z toposem niewyrażalności tematu nie jest w stanie temu podołać, gdyż ,regestrować” owe zalety, ,jedno by to było, co w Piskaryji perły, w słońcu dzień wzniecające promienie, w górnym firmamencie srebrnym lustrem iskrzące się gwiazdy liczyć" 18 . Dalej następuje wywyższenie kolejnych męskich krewnych Barbary, co ją samą, damę światłą, przyszłą autorkę i inspiratorkę życia towarzysko-kulturalnego ${ }^{19}$, stawia w cieniu zacnych panów ${ }^{20}$.

14 N. Taylor-Terlecka, Kwartet na traby - krnabrna Teofila z rodzina $w$ tle, [w:] Kobieta epok dawnych $w$ literaturze, kulturze i społeczeństwie, red. I. Maciejewska, K. Stasiewicz, Olsztyn 2008, 341-343.

R. Ocieczek, ,Staworodne wizerunki”..., s. 88.

16 Jest to tłumaczenie fragmentu słynnej Astrei d'Urfégo; zob. T. Michałowska, Romans XVII i pierwszej połowy XVIII wieku. Analiza struktury gatunkowej, [w:] Problemy literatury staropolskiej, red. J. Pelc, Seria I, Wrocław 1972, s. 454.

17 Panegirycznej sprawności Rubinkowskiego dowiódł K. Obremski w książce Panegiryczna sztuka postaciowania: August II Mocny (J. K. Rubinkowski, „Promienie cnót królewskich...”), Toruń 2003.

18 J. K. Rubinkowski, [Dedykacja] Jaśnie Oświeconej Księżnie Jejmości Barbarze z Duninów Sanguszkowej..., [w:] idem, Awantura albo historyja, światowe rewolucyje $i$ niestatecznego alternate szczęścia zamykajaca z francuskiego na ojczysty język przez [....] wyttumaczona [Historyja o Chryzeidzie i Arymancie], [Toruń] 1741, strony dedykacji bez paginacji.

19 O kulturalnej działalności marszałkowej wielkiej litewskiej, roli jej salonu towarzyskiego, jak też literackim dorobku pisały E. Aleksandrowska, O Barbarze Sanguszkowej, jej literackim salonie i nieznanej twórczości poetyckiej, [w:] Kultura literacka połowy XVIII wieku w Polsce. Studia i szkice, red. T. Kostkiewiczowa, Wrocław 1992, s. 113-145; K. Stasiewicz, Aktywność kulturowa dworu księżnej 
Świadomość reguł panegirycznej dedykacji mają same kobiety, które w tym czasie sięgają po pióro ${ }^{21}$, nawet jeśli nie posiadają wykształcenia ani literackiego obycia. Żyjąc w kulturze panegiryku, mimowolnie oswajają się $\mathrm{z}$ jego konwencją. Doskonałym na to dowodem jest przypisanie autorstwa Reginy Salomei z Rusieckich Pilsztynowej, poprzedzające jej pamiętnik. Planując wydać swe wspomnienia (czego wyraźnie dowodzi przemowa Do taskawego czytelnika), zadedykowała je „Jaśnie Wielmożnej JMP z Mniszchów Potockiej hetmanowej wielkiej koronnej pani i najosobliwszej mojej do-

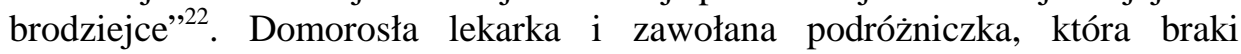

Barbary z Duninów Sanguszkowej, [w:] Dwory magnackie w XVIII wieku. Rola $i$ znaczenie kulturotwórcze, red. T. Kostkiewiczowa i A. Roćko, Warszawa 2005, s. 159-171; A. Jakuboszczak, Sarmacka dama. Barbara Sanguszkowa (1718-1791) i jej salon towarzyski, Poznań 2008.

20 To, że Rubinkowski w swym przypisaniu niewiele poświęca uwagi dokonaniom i talentom jego adresatki, na plan pierwszy wysuwając męskich przedstawicieli rodu Duninów i Sanguszków, można chyba po części wytłumaczyć tym, że księżna tak naprawdę rozwinęła swą działalność w latach późniejszych, już po śmierci męża w 1750 roku. W momencie publikacji Historyji o Chryzeidzie i Arymancie (1741) dwudziestotrzyletnia Sanguszkowa spełniała się przede wszystkim w roli żony i matki, zabsorbowanej życiem rodzinnym.

21 Świadczy o tym obszerna, dwuczęściowa dedykacja poprzedzająca romans A. Niemiryczowej Feniks rzadki na świecie, to jest przyjaciel w różnych intrygach i awanturach stateczny, JMPan Walewski wojewodzic chetmiński... (będący tłumaczeniem tekstu J. Prechaca), wydany we Lwowie w 1750 roku, skierowana do Stanisława i Józefa Lubomirskich. Autorka swe przypisanie znacząco rozbudowuje, wychwalając zarówno sam ród Lubomirskich, jak też bezpośrednich adresatów. Frapująca jest natomiast druga część dedykacji, która zawiera pewne novum. Autorka wyjaśnia w niej, dlaczego właśnie tym panom swoje dzieło ofiarowuje, wskazując na rzekomy paralelizm losów głównego bohatera tłumaczonego przez nią romansu Walewskiego - i dwóch przezacnych książąt. Ta podkreślona równoległość ma dotyczyć wytrwałości w służbie Wenery. Lubomirscy mieli wedle Niemiryczowej być w drodze do podbicia serca swych małżonek równie niestrudzeni jak romansowy amant. Czytelnik jej utworu pozna, ,[...] jakie azardy, intrygi/ znosił Walewski dla miłości ligi [...]”, a z przypisania dowiaduje się o równym poświęceniu się obu braci dla swych ukochanych, odpowiednio Ludwiki Pociejówny i Marianny Jabłonowskiej. Przywołanie postaci wybranek daje z kolei możliwość panegirycznego wyniesienia ich rodów, i po mieczu, i po kądzieli. Temu nie należy się dziwić, bo była to praktyka rozpowszechniona, natomiast warto jeszcze raz podkreślić, że poza tradycyjnymi elementami pochwalnymi wywyższeniu obu adresatów dedykacji służyło także porównanie ich do romansowych bohaterów, wytrwałych i pełnych poświęcenia dla miłości.

22 R. S. z Rusieckich Pilsztynowa, Proceder podróży $i$ życia mego awantur, wstęp R. Pollak, oprac. tekstu i przypisy M. Pełczyński, Warszawa 1957, s. 33 (z tego 
w wykształceniu nadrabiała wrodzoną ciekawością świata i ludzi, miała jako takie pojęcie, jak powinna być skonstruowana dedykacja i jak oddawać należne swym protektorom względy. Zdawała sobie też prawdopodobnie sprawę z pewnych reguł znaczących dla ówczesnego świata literackiego, które Bieńkowski wyraził następująco: „Kto umiał napisać zgrabny panegiryk - sprawdzian wiedzy, dowcipu, inteligencji i orientacji w stosunkach Europy i kraju, ten uchodził za człowieka wykształconego i dobrego pisarza" ${ }^{23}$. Pilsztynowa więc stara się, jak może, chcąc dodać powagi i wartości swej „w prostocie wyrobionej pracy". Aby zabłysnąć w dedykacji erudycją, przywołuje powszechnie wówczas uchodzący za niedościgły wzór panegiryk Pliniusza napisany na cześć cesarza Trajana ${ }^{24}$. W swej uniżonej skromności wie, jak ciężko jest sprostać zadaniu takiemu, z jakim musiał zmierzyć się rzymski autor, a ona staje w obliczu równie wielkiego. Choć jej usta nie są tak godne jak usta Pliniusza, podejmuje się jednak „na małym karteluszu” (s. 33) wyrażenia niewyrażalnych cnót prześwietnego domu Mniszchów, w którym „wszystek wybór doskonałości wspaniałości piastowane talenta założyły pomieszkanie" (s. 34). Stąd obecność chwytów powszechnie znanych, których niestety Pilsztynowa nie jest w stanie ożywić jakimś oryginalnym konceptem, a kulejący styl sprawia, że niektóre fragmenty stają się wręcz niezrozumiałe. Autorka, która o swoich przygodach pisze może nie zawsze gramatycznie poprawnie, ale dość żywo i naturalnie, w owej dedykacji nieudolnie próbuje realizować funkcjonującą konwencję, niestety z raczej żałosnym skutkiem. Można być jej wdzięcznym, że dedykacja nie jest zbyt obszerna, a pamiętnikarka ,zostawuje szczęśliwszemu pióru i wymowniejszym ustom wysławianie” (s. 34) cnót swej potencjalnej dobrodziejki.

Nie wiemy, jak układały się jej relacje z adresatką. Wbrew temu, co pisze edytor pamiętnika Roman Pollak ${ }^{25}$, to nie Ludwika z Mniszchów Potocka opiekowała się córką Pilsztynowej podczas licznych wyjazdów autorki, a inna Potocka, Konstancja z Daniłowiczów, kasztelanowa bracławska, o której

wydania pochodzą wszystkie cytaty). Dedykacja nosi tytuł: Na herbowy klejnot JW Pani z Mniszchów Potockiej Domu Jaśnie wielmożnej JMP z Mniszchów Potockiej hetmanowej wielkiej koronnej Pani i najosobliwszej mojej Dobrodziejce. Sugeruje on, że planowane przez autorkę wydanie miało być ozdobione herbem rodowym jej protektorki, co było wówczas częstą praktyką. T. Bieńkowski, op. cit., s. 191.

24 W. Bruchnalski, Panegiryk, [w:] Dzieje literatury pięknej w Polsce, cz. 2, Kraków 1918, s. 199. Mowa Pliniusza jest punktem licznych odwołań analitycznych we wspomnianej pracy K. Obremskiego. 
kilkakrotnie wspomina w swej relacji ${ }^{26}$. To jej raczej Regina Salomea powinna być wdzięczna. Wybór innej adresatki można wyjaśnić chyba tym, że pańskiej protekcji udzielał pamiętnikarce $\mathrm{w}$ sporze $\mathrm{z}$ Dominikiem Bekierskim mąż Ludwiki, hetman wielki koronny Józef Potocki. Ale w tej sytuacji można zapytać: dlaczego więc nie on jest głównym obiektem panegirycznej adoracji, a właśnie jego żona i w tym przypadku tylko ona? Tego nie sposób jednoznacznie ustalić. Ale można próbować wyjaśnić poprzez pewne analogie.

Wspomnieliśmy już o tym, iż pisząca kobieta to ciągle jeszcze novum w ówczesnych czasach, tym bardziej nowa jest sytuacja, gdy ,małe prace niewieściej prostoty" trafić mają pod prasę drukarską. Jak wiemy, panie, które w czasach saskich sięgnęły po pióro, nie kwapiły się z publikacją swych dokonań $^{27}$. Można to oczywiście uznać za przejaw charakterystycznej dla kultury barokowej niechęci do druku, ale przyczyn tego stanu rzeczy należy chyba upatrywać gdzie indziej. Niewiasty przekraczające swe stereotypowe życiowe role miały powody, by obawiać się surowszej niż piszący panowie oceny swych dokonań, czemu dawała wyraz między innymi w wypowiedziach autotematycznych poetka Elżbieta Drużbacka. Niektóre aż do śmierci nie doczekały się publikacji swej twórczości, bywa że z własnej, jasno wyartykułowanej woli, co zaświadcza $\mathrm{m}$. in. anonimowy list dedykacyjny do Historyji ksiqżęcia Ariamena Marii Beaty Zawiszanki, wydanej w 1719 roku. Nieznany „uprzejmie życzliwy i najuniżeńszy sługa” tłumaczy w nim autorce, dlaczego oddał jej utwór do druku, ponoć bez zgody zainteresowaneje, i wspomina niezrozumiały dla niego upór jej starszej siostry, Barbary z Zawiszów Radziwiłłowej, która „,trzy tomy historyji pewnej, z francuskiego języka na polski, osobliwą pracą i niewyeksplikowaną pilnością wytłumaczonej

26 B. Grosfeld, Pichelsteinowa (Pilsztynowa) z Rusieckich, 1.v. Halpirowa Salomea Regina, [w:] Polski stownik biograficzny, t. 26, Wrocław 1981, s. 31.

O tym, jak traktowała swą twórczość F. U. Radziwiłłowa i jak to wpłynęło na kwestię publikacji jej dokonań, pisze B. Judkowiak, Stowo inscenizowane. O Franciszce Urszuli Radziwitłowej - poetce, Poznań 1992 (jeden z rozdziałów tej monografii nosi znamienny tytuł wykorzystujący fragment wiersza księżnej - „...małe prace niewieściej prostoty”) oraz eadem, „Inny głos?” Wokót ekspresji kobiecości w utworach Franciszki Urszuli Radziwittowej, [w:] Kobieta epok dawnych..., s. 224.

W dedykacji powtarza się prośba o wybaczenie w związku oddaniem romansu do druku bez zgody autorki. Jest to chyba jednak tylko konwencjonalny chwyt, skoro zaraz po liście dedykacyjnym, który tak naprawdę jest skierowany nie tyle do samej Marii Beaty, co do czytelnika, następuje autotematyczna wypowiedź tłumaczki, dotycząca pewnych jej decyzji translatorskich. To pokazuje, że publikacją swej pracy nie mogła być raczej zaskoczona. 
wydać na świat nie chciała"29. Jednak pamiętajmy, że polskie społeczeństwo nie było oswojone $\mathrm{z}$ wizją kobiety pisarki i niektóre $\mathrm{z}$ autorek też nie do końca widziały się w tej roli, traktując swe literackie próby jako rodzaj intelektualnej zabawy (często warunkowanej okolicznościowymi potrzebami), która niekoniecznie jest coś warta $\mathrm{w}$ świecie zdominowanym przez twórców-mężczyzn. Wiemy, że w dobie saskiej pojawia się coraz więcej pań, którym można nadać miano rodzimych sawantek, ale ta intelektualna emancypacja rozpoczęta już w wieku XVII przebiegała powoli i nie bez oporów. Dość przypomnieć zgorszenie, jakie budził pierwszy w Polsce salon towarzyski Izabeli z Morsztynów Czartoryskiej ${ }^{30}$ czy też casus Marii Zofii Sieniawskiej, o której matka pisała w te słowa; „nazbyt ma rozumu, bo o Szwedach i wszystkich gada po francusku bardzo dobrze i po polsku". A gdy jako pięciolatka czytała w obu tych językach, obawiano się nawet, ,żeby potem nie była głupia" ${ }^{31}$. Nic dziwnego, że piszące kobiety, nawet te o znaczącej pozycji społecznej, mogły nie czuć się zbyt pewnie, gdy ktoś miał oceniać płody ich intelektu. Druk jest poważnym sprawdzianem dla każdego twórcy, w wyobrażeniu dawnych autorów pomagał go zdać splendor adresata dedykacji opromieniający również dokonania autora. Gdy pod prasę szły teksty napisane kobiecą ręką, a przypomnijmy, że nie zdarzało się to często, edytorzy zjakichś względów, szukając godnych adresatów, decydowali się, podobnie jak Pilsztynowa, na przypisanie dzieła przedstawicielkom płci pięknej.

Tak postapił wspomniany Fryczyński, dedykując dramaty księżnej Radziwiłłowej nie synowi czy ukochanemu mężowi autorki „Rybeńce”, ale właśnie jej córkom. Podobnie wybrał Józef Andrzej Załuski, przygotowując wydanie poezji Elżbiety Drużbackiej, mówiąc jego słowami, ,,arcygodnej damy a dziesiątej Muzy Sarmackiej”32. Można powiedzieć, że postarał się tu o równie ,arcygodne" adresatki. Pierwszy tom swego edytorskiego zamierzenia, którym było wydawanie wierszy „rytmopisów żyjących”33, przypisał czterem „,cnym

29 J. Miszalska zastanawia się, jaki przekład Barbary Radziwiłłowej anonimowy autor miał na myśli, bowiem według niej dokonane przez siostrę Marii Beaty tłumaczenie Dianei Loredana było oparte na oryginalnej włoskiej wersji romansu, choć znała ona również wersję francuską, zob. J. Miszalska, „Kolloander wierny” $i$ „Piękna Dianea”. Polskie przekłady wtoskich romansów barokowych w XVII wieku i w epoce saskiej na tle ówczesnych teorii romansu i przektadu, Kraków 2003, s. 330.

30 S. Sidorowicz, Czartoryska Izabela z Morstinów, [w:] Polski słownik biograficzny, t. IV, Kraków 1938, s. 241.

31 W. Konopczyński, Czartoryska Maria Zofia, [w:] Polski słownik biograficzny, t. IV, s. 248-249.

32 Cyt. za: Bibliografia polska Karola i Stanisława Estreicherów, t. 34, z. 1, Kraków 1951, s. 210, [on-line], http://www.estreicher.uj.edu.pl/baza_estreichera/skany.php?module=skany/Bibliografia_Staropolska/34_Tom_XXXIV/ [data dostępu: 24.05.2013].

33 Ibidem. 
heroinom" trzem paniom Czartoryskim: Izabeli z Morsztynów, Marii Zofii z Sieniawskich, Eleonorze z Waldsteinów oraz córce pierwszej z nich Konstancji Poniatowskiej $^{34}$. Zważywszy na pozycję owych dam, był to niewatpliwie udany chwyt marketingowy, a z punktu widzenia biografii samej Drużbackiej, powiązanej zarówno z Sieniawskimi, jak i Czartoryskimi ${ }^{35}$, całkowicie uzasadniony. Dla nas ważne jest jednak, co w obszernej dedykacji Załuski wyeksponował i jak rozłożył akcenty.

Lektura owego przypisania pokazuje, iż referendarz koronny, którego zasługi dla kultury czasów oświeceniowego przełomu trudno przecenić (bowiem używając chwytu Rubinkowskiego, ,nie tylko liczne tomy, ale też cały świat polski napełniły i napełniają"), jest w stosowanych rozwiązaniach artystycznych nieodrodnym synem przemijającej właśnie epoki. W swej prozaicznej dedykacji siega po koncepty typowe dla panegiryków doby baroku, czyniąc to oczywiście znacznie sprawniej i wytrawniej niż samouk Pilsztynowa, ale jednak nie w elegancji pomysłów, trafności obrazów (o co tak bardzo starał się autor ${ }^{36}$ ) tkwi to, co może nas zainteresować. Ważniejsze wydaje się bowiem, jak edytor wykorzystał dostojne adresatki, by zdobyć aprobatę potencjalnego czytelnika tomu. Linia panegirycznego wywyższenia biegnie tu dwutorowo, z jednej strony dotyczy pań, którym zbiór został zadedykowany, z drugiej, jakby równoległej, samej Drużbackiej. W czym tkwi owa równoległość? Wiadomo, że nie w pozycji społecznej. Członkinie rosnącej w siłę Familii i skromną szlachciankę materialnie od nich uzależniona dzieli wszak przepaść. Ale autor szuka części wspólnej, która pozwoli mu na wskazanie duchowego powinowactwa. Dlatego też w panegirycznym hołdzie kierowanym po kolei do każdej $\mathrm{z}$ cnych heroin wydobywa nie typowe dla wcześniejszej tradycji zasługi niewieście, ale predyspozycje owych dam pomocne do tego, aby właściwie ocenić doskonałość drogiego „depozytu składanego” w ich

34 J.A. Załuski, [Dedykacja] Cnym heroinom polskim, [w:] Zbiór rytmów duchownych, panegirycznych, moralnych i światowych J. Mci Elżbiety Drużbackiej skarbnikowej $\dot{z} y d a c z e w s k i e j$, zebrany $i$ do druku podany [...], Warszawa 1752, strony dedykacji bez paginacji.

K. Stasiewicz, Elżbieta $z$ Kowalskich Drużbacka w kręgu Familii, „Annales Universitatis Mariae Curie-Skłodowska”, sectio FF, vol. XX/XXI (2002/2003), s. 1-8.

S. Dąbrowski w swych rozważaniach o panegiryku przywołuje złośliwe słowa Juliana Bartoszewicza, którymi autor podsumował jedno z konceptycznych kazań Załuskiego wygłoszone w obecności królowej Marii Józefy - „przy wielkiej swej pracowitości, zacności serca i nauce, był pewnego rodzaju maniakiem. Elegancki to był niesłychanie kapłan; można by powiedzieć, że nie dla Boga, ale dla wielkiego świata się modlił, próżny do wysokiego stopnia, mawiał kazania po polsku po wszystkich kościołach, po francusku u wizytek, i [...] po włosku u Teatynów [...]". Cyt. za S. Dąbrowski, Z problematyki panegiryku, „Przegląd Humanistyczny” 1968, nr 3, s. 52. 
ręce ${ }^{37}$. I tak, jeśli sięga po motywy genealogiczne, tak częste w panegiryku, to nie po to, by w ogóle wysławić ród adresatki, jej ojców, wujów itp., którzy przysłużyli się ojczyźnie poprzez różnorodne czyny i sprawowane wyśmienicie urzędy. Izabela, „polska Cybele”, jako najstarsza i pierwsza spośród dam, godna jest powierzenia skarbu, bowiem należy „do Morsztynowskiej familiji, z której kilku arcywybranych miała Polska rytmopisów”. Jest tegoż rodu ozdobą i zaszczytem, czyli jako co najmniej równa swym utalentowanym przodkom, pozna się z pewnością na dokonaniach „Archi-Poetriji naszego wieku”. Na inny pomysł Załuski wpada w przypadku najmłodszej z adresatek, Eleonory z Waldsteinów Czartoryskiej. Skoro nie odziedziczyła zmysłu poetyckiego po swych przodkach, to może umiejętność oceny twórczości „,damy polskich literatów ozdoby” spłynie na nią od strony męża. Referendarz wymyśla tu następujący koncept: skoro jest ona kanclerzyna, a „kanclerze i pieczętarze są we wszystkich krajach naturalnemi ludzi uczonych i ich lukubracyji protektorami”, to stanie się ona $\mathrm{z}$ pewnością „najpierwszą protektorką, mecenaską i promotorek ducissą". Owa ducissa księżna protektorek - zrodziła się w głowie elokwentnego panegirysty w związku z rodową siedzibą Waldsteinów - zamkiem Dux, co ewentualnemu nieświadomemu istoty konceptu odbiorcy Załuski usłużnie podpowiada. Wywyższenie każdej z czterech adresatek ma ścisły związek z, nazwijmy to, kontekstem literackointelektualno-kulturalnym, nie zaś z zaletami, które zazwyczaj eksponowano w panegirykach poświęcanych kobietom. Otóż Konstancja Poniatowska, nie bez powodu nazwana Minerwa, to ,jubilerka rozumów”, która „,wypróbowawszy tę drogocenną w Koronie naszej perłę, nad erytrejskie i piskaryjskie perły kosztowniejszą aprobacyją swoją osądzi” i „walor właściwy lukubracyjom polskiej Muzy" przyzna. Wszystkie zacne panie mają dane ku temu, by nie tylko docenić poetyckie dokonania Drużbackiej, ale co bardzo ważne i kilkakrotnie podkreślane, jako znawczynie obronić autorkę przed natarczywymi nieprzychylnymi zoilami i rozpędzić „umbry jej talenta zazdrością ćmiące”, aby szczęśliwie „Pegaz Drużbacki” mógł „w konwoju herbowej J. O. Książąt Czartoryskich Pogoni” u „pożądanej sławy wiekopomnej” stanąć mety. Panegiryczne wywyższenie intelektualnych zalet adresatek ma tę obronę uwiarygodnić ${ }^{38}$.

37 Podobne wnioski dotyczące dedykacji Załuskiego formułuje R. Ryba w swym artykule „Jej portret” - postaci kobiet w osiemnastowiecznych listach dedykacyjnych, [w:] Dedykacje w ksiażce dawnej i wspótczesnej, red. R. Ocieczek, A. Sitkowa, Katowice 2006, s. 115-117. Do tej ważnej publikacji dotarłam dzięki życzliwej wskazówce, którą podczas konferencyjnej dyskusji otrzymałam od Pani dr hab. Bożeny Mazurkowej.

38 O postrzeganiu adresata dedykacji jako obrońcy przed ewentualną krytyką pisze R. Ocieczek, ,Staworodne wizerunki”..., s. 32-34. 
Takiego wsparcia w walce $\mathrm{z}$ ewentualnymi zarzutami potrzebował według Fryczyńskiego również tom dramatów Radziwiłłowej. Jej córki, bohaterki przypisania, nie miały w młodym wieku takiego poważania jak wielce wpływowe członkinie Familii, ale autor stara się, by dźwignia panegiryczna wyniosła je jak najwyżej. Dedykując im ,tragedyje i komedyje” matki, zaznacza, że zgodnie z tradycją dramaturgowie, chcąc wydać swe utwory, przypisywali je najzacniejszym i najdostojniejszym personom, czyli koronowanym głowom. Tu autor przywołuje adekwatne przykłady. Naśladując poprzedników, pierwszy aktor w nieświeskim teatrze dedykuje tom „Jaśnie Oświeconym Księżniczkom Dobrodziejkom", stawiając je tym samym na monarszych stopniach. Stara się to wyniesienie uzasadnić, wymieniając koligacje domu Radziwiłłowskiego z władcami Polski, nawet te sięgające odległych czasów Zygmunta Augusta i jego małżonki.

Przypomnijmy też, że obu adresatkom tomu Fryczyński przypisał wszelkie możliwe zalety płci niewieściej, które utrwaliła dotychczasowa tradycja panegiryczna. Co ważne, do urody, skromności, pokory dorzucił walory intelektu obu panien, zaznaczając przy tym, że potrafią je one właściwie wykorzystać:

[...] umiejętność i dowcip bystry wielu aż do uporczywego sprzeciwienia się przymusza, u Was na tym stanęły stopniu, na którym wszystkim jawne we wszystkich sprawiacie podziwienie i dobrą rodzą zazdrość.

Wywyższone własną doskonałością, krwią znamienitych przodków, jako „cud miłości ku rodzicom”, księżniczki będą bronić „pomocą wynalazku tego" - czyli dzieła ich matki ${ }^{39}$. Jakże znamienne jest tu sformułowanie, w zakończeniu brzmiące wręcz militarnie: „Aby w przezacnych osobach waszych dzieła tego ozdoba, powaga i obrona pogotowiu była”.

Chcąc wspomóc księżniczki w tym zadaniu, Fryczyński przedstawia w Przemowie do czytelnika panegiryczny obraz doskonałości zmarłej księżnej uzasadniający potrzebę publikacji jej sztuk. I tak Franciszka Urszula to: „najprzedniejszych cnot i przewybornych natury ozdób pani, cud mądrości, nauk wyzwolonych osobliwa estymatorka. Zgoła nic tej pani nie dostawało do zupełnej we wszystkich naukach doskonałości”. Na dodatek stawia ją w jednym

39 Wychwalone adresatki nie były niestety zbytnio zadowolone z edycji przygotowanej przez Fryczyńskiego, por. A. Sajkowski, Z dziejów teatru nieświeskiego 1748-1762 „Pamiętnik Teatralny” 1961, z. 3, s. 413. Jakość wydania ostro skrytykował J. Krzyżanowski, Talia i Melpomena w Nieświeżu. Twórczość U. F. Radziwitłowej [w:] Teatr Urszuli Radziwiłłowej, oprac. i posłowiem opatrzyła K. Wierzbicka, Warszawa 1961, s. 7. 
rzędzie z wybitnymi antycznymi dramaturgami, bowiem podobno sama księżna miała świadomość wysokiej rangi komedii i tragedii w starożytności ${ }^{40}$ i pragnęła, pisząc swe utwory, ,aby się i Polska podobnym polorem zaszczycała”. Fryczyński ani słowem się tu nie zająknął, że pomysł nazwania poszczególnych sztuk właśnie komediami bądź tragediami, mimo iż nie odpowiadały one regułom owych gatunków, pochodził od niego i że sam z własnej inicjatywy zmieniał tytuły utworów wymyślone przez księżnę ${ }^{41}$ - ów cud mądrości. Ale poprzez wspomniany wyżej chwyt panegiryczny postawił Radziwiłłową na odpowiednim stopniu doskonałości, razem z Sofoklesem i Eurypidesem.

W ramie wydawniczej doby saskiej pojawiają się zatem nowe treści, które są odpowiedzią na zmiany zachodzące w rodzimym życiu kulturalnym. Skoro na literackim Parnasie chcą zasiąść polskie panie, to nadszedł czas, by „Apollo uprzątnął im plac”42, a panegirycznie nastrojona Muza przekonała potencjalnych czytelników, że warto sięgnąć po owoce ich pisarskiego trudu.

40 Trudno odpowiedzieć na pytanie, na ile księżna rzeczywiście była zaznajomiona z dorobkiem antycznej dramaturgii. Wśród ksiąg do niej należących nie ma śladu wymienianych przez Fryczyńskiego starożytnych autorów, por. B. Judkowiak, Formacja umystowa sawantki połowy wieku [świat ksiqżek i środowisko literackie Franciszki Urszuli Radziwittowej], [w:] Kultura literacka polowy XVIII wieku w Polsce, s. 155.

41 B. Judkowiak, Wzgardzony wielogłos. Kultura teatralna czasów saskich, Poznań 2007, s. 38-39. Badaczka zaznacza w innej swej pracy, że tytuły sztuk Radziwiłłowej, zarówno te oryginalne, jak i nadane przez Fryczyńskiego, odbijają przedoświeceniową, nieklasycystyczną świadomość genologiczną ich pomysłodawców. Charakteryzowała ją „nieprzystawalność określeń «tragedia» $\mathrm{i}$ «komedia» do odnośnych jakości estetycznych i zasad kompozycji” (Franciszka Urszula Radziwittowa [1705-1753], [w:] Pisarze polskiego oświecenia, t. I, red. T. Kostkiewiczowa, Z. Golińskiego, Warszawa 1992, s. 77).

42 Por. J. E. Minasowicz, Na zbiór lukubracyji poetycznych W. JMci Pani Elżbiety z Kowalskich Drużbacki skarbnikowej ziemi żydaczewskiej, [w:] Zbiór rytmów duchownych, panegirycznych, moralnych i światowych J. Mci Elżbiety Drużbackiej $[\ldots]$, strona bez paginacji. 